\title{
World Health Organisation staging, adherence to HAART and abnormal cervical smears amongst HIV-infected women attending a government hospital in Johannesburg, South Africa
}

\author{
Appolinaire Ciamalenga Katumba**, Elizabeth Rejib ${ }^{\mathrm{b}}$ Tabither Gitau' and Cindy Firnhaber ${ }^{\mathrm{de}}$ \\ aFaculty of Health Sciences, University of the Witwatersrand, Johannesburg, South Africa \\ ${ }^{b}$ Department of Family Medicine, Faculty of Health Sciences, University of the Witwatersrand, Johannesburg, South Africa \\ cPopulation Council (Poverty, Gender and Youth Development), Kenya \\ ${ }^{d}$ Right to Care \\ eFaculty of Health Sciences, Clinical HIV Research Unit, Department of Internal Medicine, University of the Witwatersrand, Johannesburg, South \\ Africa \\ *Corresponding author, email:ackatumba@gmail.com
}

Introduction: South Africa (SA) has more people living with Human Immunodeficiency Virus (HIV) than any other country in the world. Women infected with HIV have a higher risk of developing cervical dysplasia and cancer than women who are not infected. Objective: To ascertain the correlation between the World Health Organisation (WHO) HIV staging and adherence to highly active antiretroviral therapy (HAART) with abnormal Pap smear results of HIV-infected women attending a government hospital in Johannesburg, SA.

Methods: A cross-sectional descriptive study was performed by reviewing Pap smears of 390 HIV-positive women. Adherence was measured by the patient's report and viral load. Data was collected through the use of self-administered questionnaires. Results: The prevalence of abnormal Pap smears was $57 \%$ and low grade squamous intraepithelial lesions (LGSIL) were the most common abnormality seen (142/390,36\%). WHO stage 3 participants were three times more likely to have abnormal Pap smears than those with WHO stage 1 (OR 3.3, 95\% Cl 1.23-9.04, $p=0.018)$. Abnormal Pap smears were seen more frequently in participants with a CD4 cell count $\leq 350$ cells/ $\mu$ compared to participants with CD4 cell count $\geq 500$ cells $/ \mu \mathrm{l}(p=0.001,95 \% \mathrm{Cl}$ 0.09-0.37). Participants who did not use HAART had more abnormal results compared to those who used HAART ( $p<0.028,95 \%$ $\mathrm{Cl}$ 0.28-0.93). Self-reported adherence to HAART did not show any association with abnormal Pap smears.

Conclusion: Increased immune-suppression measured by WHO staging or CD4 count increases the risk of cervical cancer precursors. The high risk group in this study was found to be participants with $\mathrm{CD} 4<350$ cells $/ \mu$ l.

Keywords: adherence to HARRT, CD4 count, HIV viral load and abnormal cervical smears, WHO staging

\section{Introduction}

Sub-Saharan Africa, a region with only $12 \%$ of the global population, has $68 \%$ of all people living with human immunodeficiency virus (HIV), with women constituting greater than $50 \%$ of the epidemic. ${ }^{1}$ The epidemic continues to be most severe in southern Africa, with South Africa having more people living with HIV (an estimated 5.6 million) than any other country in the world. ' Women infected with HIV have a high risk of developing cervical dysplasia and cancer of the cervix than women who are not infected. ${ }^{2}$ Cervical cancer is the second most common cause of cancer mortality in women worldwide, and the leading cause of cancer mortality in African women, where access to screening programmes is limited. ${ }^{1-3}$

HIV-positive status was established as a risk factor in the pathogenicity of cervical cancer. ${ }^{4}$ The CDC in 1993 declared it an acquired immunodeficiency syndrome (AIDS) defining illness. ${ }^{5}$ In addition, Moodley et al in South Africa described cervical cancer and infection with HIV as important public health problems. ${ }^{6}$ Cervical cancer is a preventable condition and Papanicolaou test is a screening tool for the early detection of cervical cancer. ${ }^{6,7}$ The Pap smear screening method has been shown to reduce mortality from cervical cancer. ${ }^{8}$
According to the South African clinical HIV treatment guidelines of 2010, all HIV-positive women require cervical cancer screening on diagnosis, and if negative, every three years thereafter irrespective of highly active antiretroviral therapy (HAART) treatment. ${ }^{9}$ Hence, performing a cervical smear as a prerequisite to pre-HAART work-up by some institutions was found justified. ${ }^{10,11}$ There are several publications that have reviewed different risk factors associated with abnormal Pap smears in HIV-positive women, such as CD4 cell count and lack of antiretroviral therapy, but little is known about the role of other factors such as World Health Organization (WHO) HIV staging and adherence to effective antiretroviral therapy use. This study's aim was thus to assess the association of the WHO staging and adherence to HAART with abnormal cervical smears among HIVinfected women attending Dr Yusuf Dadoo hospital, a level one South African government hospital located in Johannesburg.

\section{Method}

This is a cross-sectional descriptive survey, conducted in an HIV clinic (Phedisong clinic) of Dr Yusuf Dadoo hospital from 1 April 2013 to 30 June 2013. Ethical approval was obtained from the Human Research Ethics Committee of the University of the Witwatersrand (Protocol number HREC M130111). The inclusion criteria for the study were: confirmed HIV-positive test; 
Table 1: Socio-demographic characteristics of the study's participants

\begin{tabular}{|l|c|c|}
\hline Variables & Number of participants $(\mathbf{N}=390)$ & Mean \pm SD \\
\hline Age group (Years) & & $38 \pm 8.67$ \\
\hline Less than 30 & $68(16.15 \%)$ & $93(23.85 \%)$ \\
\hline $30-34$ & $80(20.51 \%)$ \\
\hline $35-39$ & $86(22.05)$ \\
\hline $40-44$ & \\
\hline More than 45 & $381(97.69 \%)$ \\
\hline Ethnic group & $9(2.31 \%)$ \\
\hline African & \\
\hline Others & $321(82.31 \%)$ \\
\hline Marital status & $69(17.69 \%)$ \\
\hline Not married & \\
\hline Married & $11(2.82 \%)$ \\
\hline Educational status & $291(74.62 \%)$ \\
\hline No education & $59(15.13 \%)$ \\
\hline Pre-matric & $29(7.44 \%)$ \\
\hline Matric & \\
\hline Post-matric & & \\
\hline
\end{tabular}

willingness to do one Pap smear test at the time of consultation; women aged 18-65 years; not menstruating at time of screening; able to give consent; able to follow the study protocol; and, did not have a serious illness that would prohibit participating in the study. Approximately 500 women attended the clinic during the study period. A directed questionnaire was given to the consented study participants by the researcher. The help of a professional nurse with translating skills was sought for the participants who did not speak English. The study participants' data relative to their socio-demographic (age, race, marital status, employment status, and educational levels) and reproductive characteristics (age at first sexual intercourse, age at first pregnancy, number of sexual partners, gravidity, contraceptive method used, and history of sexually transmitted infections) were provided by the participants, and captured by the researcher. However, these data were not used in the study. Further data (WHO HIV clinical staging (2006), CD4 cell count levels, viral load, HAART uptake, period on HAART, and HAART adherence) were collected from the patients'files. Women whose HIV viral load was greater than 1000 copies/ml despite treatment were referred for adherence counselling as per the standard of care within the clinic. Clinical examination and WHO staging were done followed by a Pap smear test using a wooden spatula and standard slide preparation in the presence of a female nursing assistant. The cytology evaluation was done by the National Health Laboratory Services (NHLS), in Braamfontein, Johannesburg, South Africa, based on the Bethesda classification system, ${ }^{12}$ and abnormal Pap smears were managed according to the South African guidelines. ${ }^{9}$

\section{Statistical methods}

STATA version 10 software was used for the statistical analysis. The descriptive analysis of the categorical variables was done and the results were presented in frequencies and percentages. For the continuous variables, means and standard deviations were computed for normally distributed variables, whereas median and interquartile ranges were reported for skewed variables. Chi-square test was used to test for the associations between WHO staging and adherence to HAART with abnormal
Pap smears. The $95 \%$ confidence interval was used to confirm the strength of associations and $p<0.05$ was considered as statistically significant.

\section{Results}

A total of 398 participants underwent Pap smears tests and were eligible for the study. Of these, eight Pap smear results were unavailable, thus the total number of the study participants was 390. Of the HIV-positive women in the clinic, 101 did not participate in the study because they were not willing to participate or to give consent $(n=77,15.4 \%)$, below age 18 years of age $(n=10,2.0 \%)$, age above 65 years of age $(n=5,1.0 \%)$, or were pilot study participants $(n=10,2.0 \%)$.

The median age of the participants in the study was 43 years with a range from 21 to 65 years. Tables 1 and 2 show demographic and sexual history of the study participants respectively.

Eighty-four percent $(328 / 390,84 \%)$ of participants were stage 1 according to the WHO HIV classification system and the median CD4 count for the study was 381 cells/ $\mu$ l. The majority of women were using HAART $(330 / 390,85 \% ; 15 \%$ of other participants were in pre-initiation phase) and $51 \%$ (198/390) of the participants had a viral load below 50 copies $/ \mathrm{ml}$. Approximately $75 \%$ (283/390) of women were on HAART for over one year and most had not changed their regimen in over a year. Eighty-four percent $(41 / 49,84 \%)$ of participants who changed their HAART treatment were on the previous HAART treatment for more than one year. Fifty-six per cent $(219 / 390,56 \%)$ of the participants reported HAART adherence for two sequential visits within a year of treatment (Table 3).

Slightly over half (222/390, 57\%) of the participants had abnormal Pap smears, low-grade squamous intraepithelial lesions (LGSIL) were the most common pathology (142/390,36\%), followed by high-grade squamous intraepithelial lesions (HGSIL; 16\%, 64/390) (Table 4). There was a statistically significant relationship between WHO staging at the time of Pap smear and abnormal Pap smears $\left(\chi^{2}=7.50, p=0.023\right)$. WHO stage 3 participants were 
Table 2: Reproductive health and sexual activities of the study's participants

\begin{tabular}{|c|c|}
\hline Variables & Number of participants $(N=390)$ \\
\hline \multicolumn{2}{|l|}{ Age group at the first sexual encounter } \\
\hline Less than 10 years & $1(0.26 \%)$ \\
\hline $10-14$ years & $10(2.56)$ \\
\hline $15-19$ years & $296(75.9 \%)$ \\
\hline 20-24 years & $78(20 \%)$ \\
\hline More than 25 years & $5(1.28 \%)$ \\
\hline \multicolumn{2}{|l|}{ Age group at the first pregnancy } \\
\hline Never fell pregnant & $16(4.1 \%)$ \\
\hline Less than and equal to 24 years & $302(77.43 \%)$ \\
\hline $25-30$ years & $56(14.36 \%)$ \\
\hline Greater than 30 years & $16(4.1 \%)$ \\
\hline \multicolumn{2}{|l|}{ Number of lifetime pregnancies } \\
\hline Never fell pregnant & $16(4.1 \%)$ \\
\hline 1-4 pregnancies & $338(86.67 \%)$ \\
\hline Greater than and equal to 5 pregnancies & $36(9.23 \%)$ \\
\hline \multicolumn{2}{|l|}{ Number of sexual partners in a lifetime } \\
\hline 1 & $31(7.95 \%)$ \\
\hline Greater than and equal to 2 & $359(92.05 \%)$ \\
\hline \multicolumn{2}{|l|}{ History of sexually transmitted diseases (STDs) } \\
\hline No history of STDs & $236(60.51 \%)$ \\
\hline Had history of STDs & $154(39.49 \%)$ \\
\hline \multicolumn{2}{|l|}{ Use of contraception (prevention) } \\
\hline Did not use contraception & $88(22.56 \%)$ \\
\hline Did use contraception & $302(77.44 \%)$ \\
\hline
\end{tabular}

three times more likely to have abnormal Pap smears as compared to those with WHO stage 1 (OR 3.3, standard error = $1.7, p=0.018,95 \% \mathrm{Cl} 1.23-9.04$ ) (Figure 1).

A statistically significant relationship was found between the non-use of HAART and Pap smears findings $\left(\chi^{2}=4.95, p=0.024\right)$. Abnormal Pap smear results were seen more frequently in participants who did not use HAART compared to those who used HAART $[42 / 60(70 \%)$ vs. $180 / 330(54.6 \%) ; p=0.028,95 \% \mathrm{Cl}$ 0.28-0.93]

The median CD4 cell count level of women not on HAART was ( $227.50 \mathrm{cells} / \mu \mathrm{l})$, lower than the median CD4 cell count of the participants who did use HAART ( 426 cells/ $\mu$ l) (Figure 2 ).

No significant relationship was found between, respectively, Pap smear results and adherence to HAART (Figure 3), and Pap smear results and viral load (Figure 4).

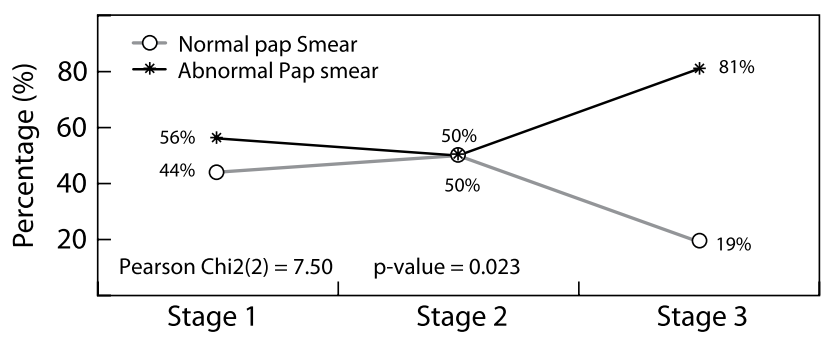

Figure 1: Association between WHO staging with abnormal Pap smears.

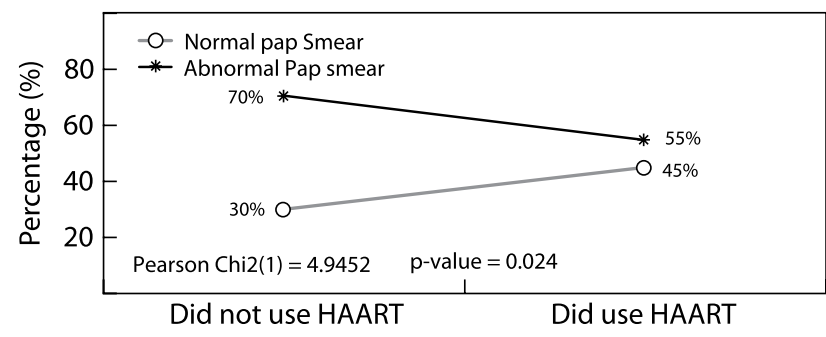

Figure 2: Association between the use of HAART with abnormal Pap smears.

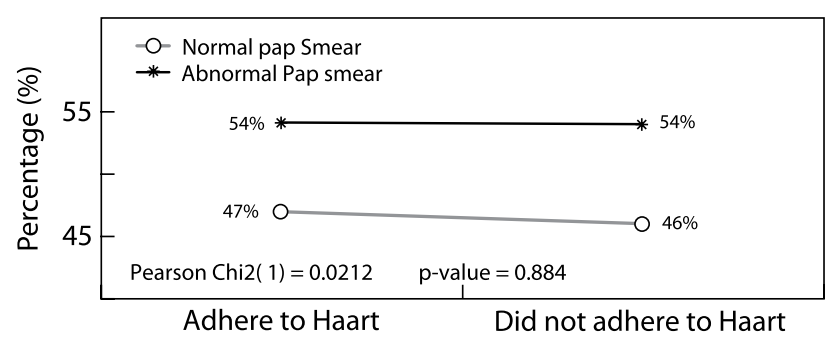

Figure 3: Association between the adherence to HAART with abnormal Pap smears.

There was a statistically significant relationship between the CD4 cell count and abnormal Pap smears $\left(\chi^{2}=29.8311, p=0.001\right)$. Participants with CD4 cell counts greater than 500 cells $/ \mu$ l had fewer abnormal Pap smears $(48 / 117,41 \%)$ compared to those with CD4 cell counts less than 350 cells/ $\mu$ l (122/172, 70.9\%) (Table 5 and Figure 5). 
Table 3: Clinical characteristics of the study's participants

\begin{tabular}{|c|c|}
\hline Variables & Number of participants $(N=390)$ \\
\hline \multicolumn{2}{|l|}{ WHO staging } \\
\hline Stage 1 & $328(84.1 \%)$ \\
\hline Stage 2 & $36(9.23 \%)$ \\
\hline Stage 3 & $26(6.67 \%)$ \\
\hline Stage 4 & $0(0.00 \%)$ \\
\hline \multicolumn{2}{|l|}{ Most recent CD4 cell count at the time of the pap smear (in cell/ $\mu \mathrm{l}$ ) } \\
\hline Less than 200 & 59 (15.13\%) \\
\hline 200-349 & $113(28.97 \%)$ \\
\hline $350-499$ & $101(25.9 \%)$ \\
\hline Greater than and equal to 500 & $117(30 \%)$ \\
\hline \multicolumn{2}{|l|}{ Viral load (in copies/ml) } \\
\hline Viral load not done (Participants not on HAART and participants on HAART for a period of less than 6 months) & $66(16.92 \%)$ \\
\hline Less than 50 & $198(50.77 \%)$ \\
\hline $50-399$ & $69(17.69 \%)$ \\
\hline 400-999 & $16(4.1 \%)$ \\
\hline Greater than and equal to 1000 & $41(10.51)$ \\
\hline \multicolumn{2}{|l|}{ Use of HAART } \\
\hline Did not use HAART & $60(15.38 \%)$ \\
\hline Did use HAART & $330(84.62 \%)$ \\
\hline \multicolumn{2}{|l|}{ Duration of current HAART treatment } \\
\hline Did not use HAART as treatment & $60(15.38 \%)$ \\
\hline Less than 6 months & $17(4.36 \%)$ \\
\hline 6 months-1 year & $30(7.69 \%)$ \\
\hline Greater than 1 year & $283(72.56 \%)$ \\
\hline \multicolumn{2}{|l|}{ History of most recent switch of HAART treatment } \\
\hline Did not use HAART treatment & $60(15.38 \%)$ \\
\hline Did not switch off HAART treatment & $281(72 \%)$ \\
\hline Did switch off HAART treatment & $49(12.56 \%)$ \\
\hline If any switch off HAART treatment, the duration of the previous HAART treatment & $N=49$ \\
\hline Less than 6 months & $4(8.16 \%)$ \\
\hline 6 months-1 year & $4(8.16 \%)$ \\
\hline Greater than 1 year & $41(83.67 \%)$ \\
\hline Self-reporting of adherence to HAART for 2 sequential visits within 12 months of treatment & $N=390$ \\
\hline Adherent & $219(56.15 \%)$ \\
\hline Not adherent & $105(26.92 \%)$ \\
\hline Participants not on HAART and participants on HAART for a period of less than 6 months. & $66(16.92 \%)$ \\
\hline
\end{tabular}

Table 4: Current Pap smear results of the study's participants

\begin{tabular}{|l|c|}
\hline Pap smear results & Number of participants $(\mathbf{N}=390)$ \\
\hline Normal & $168(43.08 \%)$ \\
\hline Abnormal & $222(56.92 \%)$ \\
\hline Atypical squamous cells of undetermined significance (ASCUS) & $16(4.1 \%)$ \\
\hline Low grade squamous intraepithelial lesions (LGSIL) & $142(36.41 \%)$ \\
\hline High grade squamous intraepithelial lesions (HGSIL) & $64(16.41 \%)$ \\
\hline
\end{tabular}

\section{Discussion}

The prevalence of abnormal Pap smears in our group was 57\%. Similar observations were reported in Cameroun and Nigeria. ${ }^{2,13-15}$ Contrary to our observations, the prevalence of abnormal Pap smears was found to be below $50 \%$ in some studies from South Africa and Thailand. ${ }^{16,17}$ The difference might be due to the study sample, HIV prevalence, access to screening, HAART, and the extent of illness presented by the participants (WHO-HIV stage). 


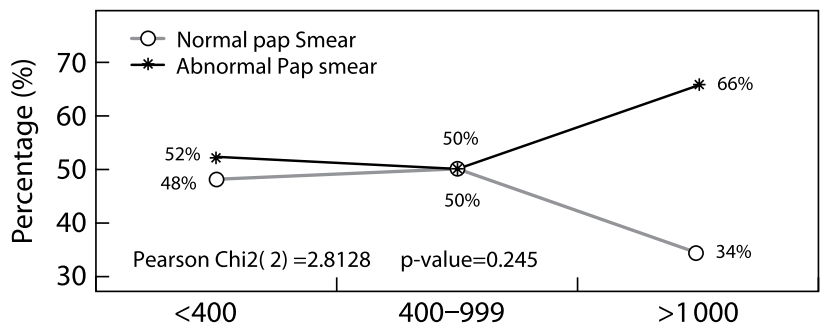

Figure 4: Association between viral load with abnormal Pap smears.

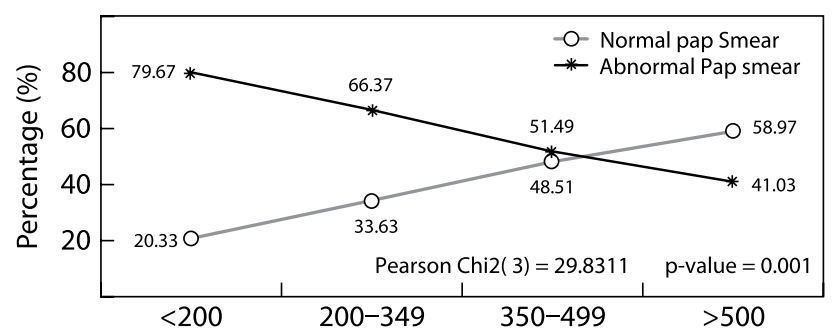

Figure 5: Association between CD4 cell count with abnormal Pap smears.

LGSIL were the most common pathology (142/390, 36.41\%), followed by HGSIL $(64 / 390,16.41 \%)$. Similar findings were seen by Dames et al. in the United States of America. ${ }^{18}$ Eighty-one percent $(81 \%)$ of their study participants $(81 / 100)$ were on HAART. Of these, 31\% (31/100) had LGSIL and 6\% (6/100) had HGSIL. The above findings contradict the findings reported by Tansupswatdikul et al. ${ }^{17}$ in Thailand, where $82.1 \%$ (230/280) of their participants were on HAART. Of those, $6.4 \%$ had LGSIL $(18 / 280)$ and $12.1 \%$ had HGSIL (34/280). Our findings, and those of Dames et al., are also contrary to those of Gaym et al. in South Africa, ${ }^{16}$ although their study was limited by the absence of information regarding how many participants were on HAART. They found that $21 \%(24 / 114)$ of their study group had LGSIL and $4.3 \%(5 / 114)$ had HGSIL. The study sample size might have played a role in this difference.

The present study confirms that there is a high risk of cervical cancer precursors in HIV-infected women, emphasising the importance of the cervical screening in all HIV-infected women.

Our study confirms the findings of many other studies that HIVinfected women in southern Africa have high rates of cervical disease, notwithstanding the fact that most of the study participants were stage 1 in the WHO-HIV classification. Furthermore, our findings indicate that women classified as WHO stage 3 are three times more likely to develop significant cervical dysplasia. In a retrospective study of cervical smears in HIV-infected postnatal women at Johannesburg Hospital, South Africa, WHO-HIV stage 1 was seen in $31 \%$ of the study population. ${ }^{19}$ Although the study sample was almost equal in demography to this study, the difference might be due to the selection of the participants (postnatal HIV-positive women). This study's findings of $7 \%$ of participants in WHO-HIV stage 3 differs from the study of Memiah et al. who found that more than $30 \%$ of their study participants were in WHO-HIV stage $3 .{ }^{20}$ The difference might be explained on the basis that sicker patients were excluded from our study. There was a statistically significant relationship between WHO staging and abnormal Pap smears $\left(\chi^{2}=7.50, p=0.023\right)$. WHO stage 3 participants were three times more likely to have abnormal Pap smears than those with WHO stage 1 (OR 3.3, 95\% Cl 1.23-9.04, $p=0.018$ ). Thus, the more advanced the WHO-HIV stage in a woman, the greater the chance of having an abnormal Pap smear. This contradicts the findings made by Wise ${ }^{18}$ in Johannesburg who found that the WHO stage did not appear to have an impact on the final analysis of the Pap smear. The difference in results relates to the fact that the study design was retrospective with $45 \%$ missing data relating to their participants' WHO staging.

In this study, there was a statistically significant relationship between the non- use of HAART and abnormal Pap smears. Abnormal Pap smears were seen more in participants who did not use HAART as compared to those who used HAART. Although women on HAART had less abnormal cervical smears and these were mainly LGSIL, there was still a minority with HGSIL. This correlates with the observations made by many authors in the literature. ${ }^{15,20,21}$ Thus, the immune reconstitution resulting from HAART might not be enough to prevent the development of severely abnormal cervical smears in all HIV-infected women. This observation might be due to the fact that women often start HAART with CD4 counts below 200 cells/ $\mu$ l and so would have had lower CD4 cell count nadirs and developed cervical dysplasia before immune-reconstitution, precluding any improvement of cervical disease with a bolstered immune system. The duration on HAART was not looked at in this study; this may be a confounding factor and requires further evaluation in future research.

No association was found between adherence to HAART and abnormal Pap smears in HIV-infected women who participated in this study ( $p=0.884)$. The same observation was made by Leibenson et al. ${ }^{21}$ in Israel where HAART compliance was not found to have an impact on HPV prevalence $(p=0.525)$. The above observation contradicts the findings by Minkoff et al..$^{22}$ in a prospective cohort study in the USA where adherence to HAART was associated with a significant reduction of squamous intraepithelial lesions. This difference may be attributed to the fact that it was a prospective cohort study ( 2.5 years) with a semiannual follow-up Pap smear during the period their study participants were on HAART (2.5 years). The participants' selfreporting of HAART in this study may have also contributed to

Table 5: Association CD4 cell count with abnormal pap smears

\begin{tabular}{|c|c|c|c|c|c|c|c|}
\hline \multicolumn{2}{|l|}{ Variables } & \multicolumn{2}{|c|}{$\begin{array}{c}\text { Normal Pap smears } \\
\qquad n=168\end{array}$} & \multicolumn{2}{|c|}{$\begin{array}{l}\text { Abnormal Pap smears } \\
\qquad n=222\end{array}$} & \multirow[t]{2}{*}{$p$-value } & \multirow[t]{2}{*}{$\begin{array}{c}95 \% \text { confidence } \\
\text { interval }\end{array}$} \\
\hline CD4 cell count (in cell/ $\mu \mathrm{l}$ ) & Total number $N=390$ & Number & Percentages & Number & Percentages & & \\
\hline Less than 200 & 59 & 12 & 7.14 & 47 & 21.17 & & \\
\hline $200-349$ & 113 & 38 & 22.62 & 75 & 33.78 & 0.071 & $0.24-1.06$ \\
\hline $350-499$ & 101 & 49 & 29.17 & 52 & 23.42 & 0.001 & $0.13-0.57$ \\
\hline Greater than 500 & 117 & 69 & 41.07 & 48 & 21.62 & 0.000 & $0.09-0.37$ \\
\hline
\end{tabular}

Notes: Pearson $\chi^{2}(3)=29.8311$.

$p$-value $=0.001$. 
this difference as a reporting bias could significantly impact on the final outcome of this current study.

Although viral load is a good surrogate indicator for antiretroviral drug adherence, no relationship between viral load and abnormal Pap smears was found ( $p=0.245$ ). This finding concurs with the cross-sectional study done by Leibenson et al..$^{21}$ in Israel in which no statistically significant effect of viral load on HPV prevalence was found ( $p=0.277$ ). In a cross-sectional study by Cardillo et al. ${ }^{23}$ in USA, however, the median HIV viral load from the patients with squamous intraepithelial lesions (SILs) was significantly higher than that from those with normal Pap smears (109 316 copies $/ \mathrm{ml}$ vs. 41602 copies $/ \mathrm{ml} ; p=0.006$ ). The difference with this current study may be related to the duration of the study ( 5 years), HAART regimen and the absence of treatment compliance data. The same observation was made by Swende et al. ${ }^{13}$ in Nigeria where the median HIV viral load of their study participants on HAART was significantly higher in women with SIL compared with that of women without SIL (102 705 copies/ml vs. 64391 copies/ml, respectively; $p=0.002)$. The difference may be due to the fact that in their study more participants (205/253, 81\%) had a viral load of greater than 400 copies $/ \mathrm{ml}$ compared to those in the current study where most participants were virologically suppressed (269/324, 82.4\%). Although no significant relationship between viral load and abnormal Pap smears was seen in this study, the graph in Figure 4 demonstrates a trend that the higher the viral load count, the more abnormalities were seen in the Pap smears. Similar findings are illustrated in the graph showing the association between WHO staging and abnormal Pap smears (Figure 1). Small numbers may not have allowed enough power to detect a difference in this study.

A significant statistical relationship between CD4 cell counts and abnormal Pap smears was found. The participants with CD4 cell counts greater than 500 cells/ $\mu$ l presented with lower number of abnormal Pap smears $(48 / 222,41 \%)$ compared to those with CD4 cell counts of less than 350 cells/ $\mu$ (75/222, 66.37\%). Even though a CD4 cell count between 350 to 499 also had a lower number of abnormal Pap smears (52/222, 51\%), the cut-off treatment with CD4 cell counts greater than 500 cells/ $\mu$ l might help significantly in reducing the prevalence of cervical dysplasias in the setting where affordability for HAART is guaranteed. This association with the immune status of HIVinfected women has been reported by many authors ${ }^{4,20,24}$ in the literature, where more Pap smear abnormalities were found with a CD4 cell count $<200$ cells $/ \mu{ }^{13,17,19,20,25-27}$ A CD4 cell count of more than 500 cells/ $\mu \mathrm{l}$ might be a useful tool in the stratification of the risk in developing cervical abnormalities or cervical cancer in HIV-positive women.

\section{Conclusion}

In our study, an association was found between WHO staging, the use of HAART, current CD4 cell counts and abnormal Pap smears among HIV-infected women attending Dr Yusuf Dadoo Hospital. Therefore, some recommendations are to be considered: cervical cancer screening is imperative in HIV-infected women and provision of more screening in HIV-positive women with advanced immunosuppression; and, screening targets should be set and monitored at the health care clinics. Initiating HAART at CD4 cell counts greater than 500 cells $/ \mu$ l should be considered as this might help reduce the prevalence of cervical dysplasias. Finally, adherence counselling should be given generally to all HIVinfected women and specifically to those at high risk of defaulting.
WHO HIV CLINICAL STAGING (2006)

STAGE 1:

- ASYMPTOMATIC

- PERSISTENT GENERALIsED LYMPHADENOPATHY

STAGE 2:

- UNEXPLAINED MODERATE WEIGHT LOSS $(<10 \%$ OF PRESUMED OR MEASURED BODY WEIGHT)

- RECURRENT RESPIRATORY TRACT INFECTIONS (SINUSITIS, TONSILLITIS, OTITIS MEDIA AND PHARYNGITIS)

- HERPES ZOSTER

- angular Chelitis

- RECURRENT ORAL ULCERATION

- PAPULAR PRURITIC ERUPTION

- SEBORRHOEIC DERMATITIS

- FUNGAL NAIL INFECTIONS

STAGE 3:

- UNEXPLAINED SEVERE WEIGHT LOSS (> 10\% OF PRESUMED OR MEASURED BODY WEIGHT)

- UNEXPLAINED CHRONIC DIARRHOEA FOR LONGER THAN ONE MONTH

- UNEXPLAINED PERSISTENT FEVER (ABOVE $37.5^{\circ} \mathrm{C}$ INTERMITTENT OR CONSTANT, FOR LONGER THAN ONE MONTH.

- PERSISTENT ORAL CANDIDIASIS

- ORAL HAIRY LEUKOPLAKIA

- PULMONARY TUBERCULOSIS

- SEVERE BACTERIAL INFECTIONS (SUCH AS PNEUMONIA, EMPYEMA, PYOMYOSITIS, BONE OR JOINT INFECTION, MENINGITIS OR BACTERAEMIA)

- ACUTE NECROTISING ULCERATIVE STOMATITIS, GINGIVITIS OR PERIODONTITIS

- UNEXPLAINED ANAEMIA $(<8 \mathrm{G} / \mathrm{d})$ ), NEUTROPAENIA $\left(<0.5 \times 10^{\circ}\right.$ PER LITRE) AND/OR CHRONIC THROMBOCYTOPAENIA ( $<50 \times 10^{\circ}$ PER LITRE)

STAGE 4:

- HIV-WASTING SYNDROME (WEIGHT LOSS OF > 10\%, PLUS EITHER UNEXPLAINED CHRONIC DIARRHOEA ( $>1$ MONTH) OR CHRONIC WEAKNESS AND UNEXPLAINED PROLONGED FEVER ( $>1$ MONTH).

- PNEUMOCYSTIS PNEUMONIA

- RECURRENT SEVERE BACTERIAL PNEUMONIA

- CHRONIC HERPES SIMPLEX INFECTION (OROLABIAL, GENITAL OR ANORECTAL OF MORE THAN ONE MONTH'S DURATION OR VISCERAL AT ANY SITE)

- OESOPHAGEAL CANDIDIASIS (OR CANDIDIASIS OF TRACHEA, BRONCHI OR LUNGS)

- EXTRAPULMONARY TUBERCULOSIS

- KAPOSI'S SARCOMA

- CMV INFECTION (RETINITIS OR INFECTION OF OTHER ORGANS)

- CNS TOXOPLASMOSIS

- HIV ENCEPHALOPATHY (DISABILITY COGNITIVE AND/OR MOTOR DYSFUNCTION INTERFERING WITH ACTIVITIES OF DAILY LIVING, PROGRESSING OVER WEEKS TO MONTHS, IN THE ABSENCE OF A CONCURRENT ILLNESS OR CONDITION OTHER THAN HIV INFECTION WHICH COULD EXPLAIN THE FINDINGS)

- EXTRAPULMONARY CRYPTOCOCCOSIS INCLUDING MENINGITIS

- DISSEMINATED NON-TUBERCULOUS MYCOBACTERIAL INFECTION

- PROGRESSIVE MULTIFOCAL LEUKOENCEPHALOPATHY

- CHRONIC CRYPTOSPORIDIOSIS

- CHRONIC ISOSPORIASIS

- DISSEMINATED MYCOSIS (EXTRA-PULMONARY HISTOPLASMOSIS OR COCCIDIOMYCOSIS

- RECURRENT SEPTICAEMIA (INCLUDING NON-TYPHOIDAL SALMONELLA)

- LYMPHOMA (CEREBRAL OR B-CELL NON-HODGKIN'S)

- INVASIVE CERVICAL CARCINOMA

- ATYPICAL DISSEMINATED LEISHMANIASIS

- SYMPTOMATIC HIV-ASSOCIATED NEPHROPATHY

- SYMPTOMATIC HIV-ASSOCIATED CARDIOMYOPATHY 
Acknowledgments - We would like to acknowledge the entire staff of Phedisong clinic. We would like to acknowledge the West Rand Health district, the management of DrYusuf Dadoo hospital for authorising this study to be undertaken in their jurisdiction. Lastly, we would like to thank the patients who consented to participate in this study. The research was funded by the researcher's personal funds.

\section{Author's contributions}

Dr AC Katumba conceived and designed the study, wrote the manuscript and analysed the data. Dr E Reji and Prof C Firnhaber helped in supervising of the protocol, designed the study, analysing the data and in preparing the manuscript. Ms T Gitau helped with statistical interpretation of the results and writing of the manuscript.

\section{Competing interest - The authors declare no competing interest.}

\section{References}

1. UNAIDS World AIDS day report [cited 2012 Jan 30]. 2011 Nov. Available from: www.unaids.org/en/media/unaids/contentassets/ documents/unaidspublication/2011/JC2216_WorldAIDSday_ report_2011_en.pdf.

2. Denny $L$, Boa $R$, Williamson $A L$, et al. Human papillomavirus infection and cervical disease in human immunodeficiency virus-1-infected women. Obstet Gynecol. 2008;111:1380-7.

3. Maiman M, Tarricone N, Vieira J, et al. Colposcopic evaluation of HIVseropositive women. Obstet Gynecol. 1991;78:84-9.

4. Klein RS, Ho G. Y. F., Vermund SH, et al. Risk factors for squamous intraepithelial lesions on pap smear in women at risk for human immunodeficiency virus infection. JID. 1994;170:1404-9.

5. Centers for Disease Control and Prevention, MMWR. Recommendations and report-1993 Revised classification system for HIV infection and expanded surveillance case definition for AIDS among adolescents and adults [cited 2012 Jan 30]. 2011 Jan. Available from: http://www.cdc.gov/mmwr/preview/mmwrhtml/00018871. htm.

6. Moodley JR, Hoffman M, Carrara H, et al. HIV and pre-neoplastic and neoplastic lesions of the cervix in South Africa: a case-control study. BMC Cancer. 2006;6:135.

7. Navarra A, Pavia C, Piselli P, et al. Knowledge and practice of Pap smear-test screening among HIV-positive women. Program and abstracts of the 12th Conference on Retroviruses and Opportunistic Infections [cited 2012 Jan 2]. Boston, MA, 2005 Feb 22-25. Available from: http://www.retroconference.org/2005/CD/PDFs/980.pdf.

8. Suba E, Raab S. Lessons learned from successful papanicolaou cytology cervical cancer prevention in the socialist republic of Vietnam. Diagnostic Cytopathol. 2012;40:355-66.

9. The South African Ministry of Health. The National Guidelines on cervical cancer screening programme [cited 2013 Mar 12]. Pretoria, 2010. Available from: http://www.sahivsoc.org/practise-guidelines/ sa-dept-of-health-guidelines.

10. Centers for Disease Control. 1997 USPHS/IDSA Guidelines for the prevention of opportunistic infections in persons infected with human immunodeficiency virus. MMWR 1997;46: 1-26.

11. Franceschi $S$, Jaffe $H$. Cervical cancer screening of women living with hiv infection: a must in the era of antiretroviral therapy. CID. 2007:45:510-3.
12. Solomon D, Davey D, Kurman R, et al. The 2001 Bethesda system terminology for reporting results of cervical cytology. JAMA. 2002;287:2114-9.

13. Swende TZ, Ngwan SD, Swende LT. Prevalence and risk factors for cervical squamous intraepithelial lesions among women infected with HIV-1 in Makurdy, Nigeria. IJWH. 2012;4:55-60.

14. Firnhaber C, Zungu K, Levin S, et al. Diverse and high prevalence of human papillomavirus associated with a significant high rate of cervical dysplasia in human immunodeficiency virus-infected women in Johannesburg, South Africa. Acta Cytol. 2009;53(1):10-7.

15. Mogtomo MLK, Malieugoue LCG, Djiepgang C, et al. Incidence of cervical disease associated to HPV in human immunodeficiency infected women under highly active antiretroviral therapy. IAA Cancer. 2009;4:9.

16. Gaym A, Mashego M, Kharsany ABM, et al. High prevalence of abnormal pap smears among young women co-infected with HIV in rural South Africa - implications for cervical cancer screening policies in high HIV prevalence populations. SAMJ. 2007;97(2):115.

17. Tansupswatdikul P, Piyaman S. Prevalence and predictors of abnormal cervical cytology in HIV-Infected patients at the anonymous clinic Chonbury Hospital. TJOG. 2009;17:52-6.

18. Dames DN, Ragin C, Bowe AG, et al. The prevalence of cervical cytology abnormalities and human papillomavirus in women infected with human immunodeficiency virus. IAAC. 2009;1(4):S8.

19. Wise AJ. A retrospective review of cervical smears in human immunodeficiency virus infected postnatal women at Johannesburg hospital (Research report submitted in partial fulfilment of the requirements for the degree of Master of Medicine in the branch of Obstetrics and Gynaecology). 2010 [cited 2011 Jun 4]. Available from: http://wiredspace.wits.ac.za/handle/10539/9157?show=full.

20. Memiah P, Mbuthia W, Kiiru G, et al. Prevalence and risk factors associated with precancerous cervical cancer lesions among HIVinfected women in resource-limited settings. ART. 2012;2012: 1-7.

21. Leibenson L, Banani S, Borer A, et al. The prevalence of human papillomavirus and cervical cytology abnormalities in women infected with human immunodeficiency virus in Southern Israel. IMA. 2011;13:34-8.

22. Minkoff H, Zhong Y, Burk RD, et al. Influence of adherent and effective antiretroviral therapy use on human papillomavirus infection and squamous intraepithelial lesions in human immunodeficiency viruspositive women. JID. 2010;201:681-90.

23. Cardillo M, Hagan R, Abadi J, et al. CD4 T-cell count, viral load, and squamous intraepithelial lesions in women infected with the Human Immunodeficiency Virus. ACA. 2000;2(93):112-3.

24. Cohen MS, Chen YQ, McCauley M, et al. Prevention of HIV-1 infection with early antiretroviral therapy. N Engl J Med. 2011;365(6):493-505.

25. Moodley JR, Constant D, Hoffman M, et al. Human papillomavirus prevalence, viral load and pre-cancerous lesions of the cervix in women initiating highly active antiretroviral therapy in South Africa: a cross-sectional study. BMC Cancer. 2009;9:275.

26. Hawes SE, Critchlow CW, Faye Niang MA, et al. Increased risk of highgrade cervical squamous intraepithelial lesions and invasive cervical cancer among african women with human immunodeficiency virus type 1 and 2 infections. JID. 2003;188:555-63.

27. Kreitchmann R. Prevalence of Pap smear abnormalities in HIVinfected women in the STI/AIDS municipal center of Porto AlegreBrasil [cited 2013 Apr 8]. Poster Presentation: The $1^{\text {st }}$. IAS Conference on HIV Pathogenesis and Treatment: Abstract no.793. Available from: http://aids2014.org/Default.aspx?pageld=12\&abstractld=793.

Received: 26-06-2015 Accepted: 30-11-2015 